\title{
Fra dyrlæge Rasmus Bjorholms praksis
}

\author{
Af H.P. Jensen
}

Tæt op ad vejen mellem Bevtoft og Toftlund ligger en stor gammel gård, firlænget, omgivet af en lille klynge huse og store træer. Det er Nørre Rangstrup kommunes største gård, omkring 200 hektar stor. Over porten indtil gårdspladsen står der Bjorholmsminde. Den Bjorholm, der mindes, er dyrlæge og gårdejer Rasmus Peder Lauridsen Bjorholm, der blev født i Ørderup i 1837, søn af gårdejer, sognefoged og dannebrogsmand Jes Bjorholm. Den unge Rasmus havde lyst til andet end landbruget. Allerede i 1853 rejste han til København og begyndte at læse på Landbohøjskolen. 21 år gammel blev han dyrlæge i 1858 og praktiserede derefter i 18 år fra fødegården i Ørderup. I 1876 købte han fætteren Peter Bertramsen Bjorholms gård i Gøtterup, den nuvxrende Bjorholmsminde, dengang på 6 ottinger og omkring 160 hektar stor.

Bjorholmslægten er en af de længstboende på Toftlundegnen. $\mathrm{Da}$ museumsinspektør Jens Frost i Ābenrå i 1930'erne udarbejdede dens slægtstavle, heftede han sig særlig ved dyrlæge Rasmus Bjorholm og beskrev ham som en glimrende dansk mand, respekteret og kendt viden om for faglig dygtighed og med et uovertruffet kendskab til folk og forhold $\mathrm{i}$ hele Midtsønderjylland. Han virkede på den nye bopæl indtil september 1896, hvor han blev ramt af en smertefuld sygdom. Han døde den 11. jan. 1897 i København efter en operation og ligger begravet på Tislund kirkegård.

Rasmus Bjorholm førte meget omhyggelige regnskabsbøger og kopi af al korrespondance. I det væsentlige er hans arkiv endnu bevaret, og selv et overfladisk studium af dette viser, at her foreligger et værdifuldt kildemateriale.

Af regnskabsbøgerne ses, at fra 1876 til 1896 lå hans praksis på 
mellem 615 og 915 besøg med et gennemsnit på cirka 860 besøg årligt. Dette gennemsnit varierer ubetydeligt år efter år og er udtryk for, hvad den virksomme mand rent fysisk kunne overkomme i en tid, hvor al rejse måtte foregå med hest og vogn. $\mathrm{Da}$ han på dette tidspunkt var eneste praktiserende dyrlæge i Nørre Rangstrup herred og flere tilstødende sogne, må hans udebesøg vurderes på baggrund af of te daglange rejser. Han ses samme dag at have praktiseret $i$ for eksempel Gabol, Nustrup, Kastrup og Arnum eller ved anden lejlighed i Bevtoft, Rangstrup og Bovlund. Tilkaldelse måtte ske ved bud fra den sygdomsramte ejendom, og behandling har kun sjældent kunne ske samme dag, der kom bud. I 1890'erne begyndte en budtjeneste fra telegraf- og telefonstationer så småt at aftegne sig. Adskillige tilkaldelser er sket ved brevpost; men almindeligst har været en art løbertjeneste fra den enkelte landsby, hvor letbenede unge mænd og drenge har tjent sig en god skilling ved budtjeneste. $\mathrm{Da}$ dyrlægen måtte opgive sin praksis i september 1896, blev der foretaget en slutincassation af udestående fordringer. $P a ̊$ grundlag af de enkelte års regnskaber og afslutningen er det muligt at stedfæeste Rasmus Bjorholms praksis ret nøje. Den efterstående statistik har kun interesse ved at vise, hvor udstrakt en praksis kunne være $i$ slutningen af 1800-tallet.

\begin{tabular}{lcc}
\hline & $\begin{array}{c}\text { Udestående honorarer } \\
\text { ved praksis ophør }\end{array}$ & $\begin{array}{c}\text { Udebesøg i } \\
1895\end{array}$ \\
\hline Toftlund sogn & 83 & 149 \\
Agerskov sogn & 121 & 235 \\
Branderup sogn & 39 & 72 \\
Tislund sogn & 27 & 56 \\
Bevtoft sogn & 59 & 104 \\
Arrild sogn (særligt Roost) & 25 & 65 \\
Højrup sogn & 15 & 21 \\
Gram (Kastrup egnen) & 32 & 34 \\
Vedsted (Over Jerstal egnen) & 17 & 29 \\
Nustrup sogn & 39 & 26 \\
Diverse (eks. Spandet, Nørre Løgum, Uge) & 34 & 124 \\
\cline { 2 - 3 } & 491 & 915
\end{tabular}

Diverse-besøgene omfatter et stort antal besigtigelser og attester, ofte rekvireret af offentlige instanser langt uden for dyrlægens bopæl eller af storre handelsmand ved husdyrstridigheder eller til bedømmelse af særligt værdifulde dyrs sygdomme. 
Som eneste dyrlæge i midtlandet ses Rasmus Bjorholm of te benyttet i retsanliggender, såvel til besigtigelser som opmand i husdyrstridigheder, der beroede på solgte dyrs sundhedstilstand. På dette felt har han nydt megen respekt, skønt han kraftigt må have irriteret tyske instanser ved konsekvent at udfærdige responsa på dansk. Hans skøn og afgørelser er udarbejdet sxrdeles grundigt, affattet i et smukt letlæseligt sprog og umiddelbart forståelige for ikke fagkyndige. Hans skrift er sirlig og ren, og ved flere lejligheder vides hans indlæg at være fremhævet på bekostning af kollegers tungtvidenskabelige arbejder.

Uanset en stor arbejdsbyrde har Rasmus Bjorholm fundet tid til lobende at holde sin viden ajour, og lejlighedsvis har han affattet arbejder over emner, der særligt har interesseret ham. Et eksempel herpå lyder: Om indre blødninger ved husdyr. Om disse arbejder har været offentliggjort har desværre ikke kunnet skaffes oplyst. I praksis er han jævnligt stødt på specielle og for kolleger interessante tilfælde, som han har beskrevet meget nøje. Da dyrlæger var så få, som tilfældet var, er han ofte stødt på husråd og lægmænd, der fuskede $\mathrm{i}$ faget. Den modne, indsigtsrige mand og velhavende gårdejer lod sig på ingen måde irritere heraf. Tværtimod opskrev han omhyggeligt husrådenes ingredienser og behandlingsmådernes detaljer og underkastede dem en vurdering. I mange tilfælde indrømmede han en videnskabelig baggrund for disses større eller mindre virkning. Sådant har han allerede tidligt stiftet bekendtskab med som dreng på landet, og ved det storsind, hvormed han påhørte og betragtede alt forefaldende, vandt han kun yderligere tillid. En del af hans praksis er sket ved, at for eksempel får, heste og kreaturer bragtes til hans bopxl til behandling, hvis dyrene selv kunne bevæge sig eller fragtes. Han synes at have kunnet instruere sin kundekreds til sygdomsbeskrivelser, der tillod ordination af medicin på hans bopxl, og han har rundhåndet uddelt vejledning og instruktion til brug ved enkle letbedømmelige skader eller sygdomme. Der har været så meget at bestille for ham, at meget simpelthen har måttet tilrettelægges rationelt.

Besøgene $i$ praksis skete med hest og vogn, oftest en såkaldt arbejdsfjedervogn med god plads i kassen og beskyttet af voksdug. Her lå hans instrumenter og rejseapotek, som man kan se det hos vor tids dyrlæger. Med årene måtte dyrlægen have en karl med til kuskehjælp og ved anstrengende operationer, selv om bestemte greb, hvormed 


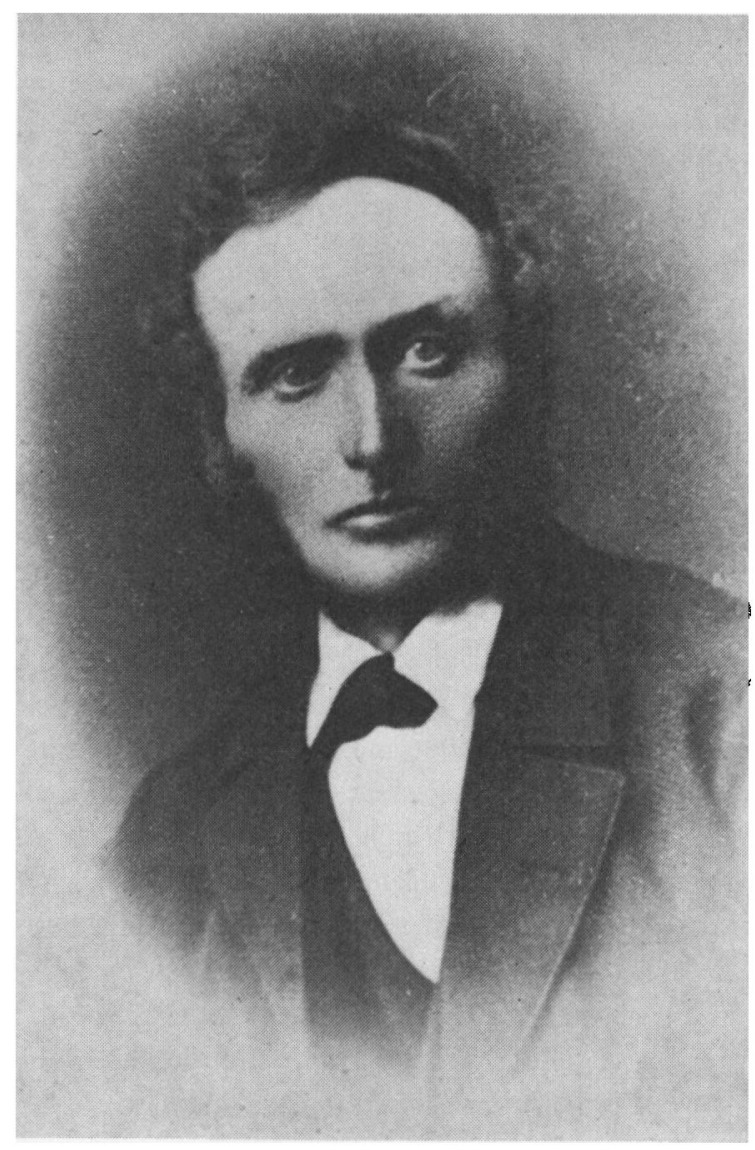

Dyrlage Rasmus Bjorbolm (1837-97).

dyr kastes, sluttelig ikke kunne gøres bedre end af manden selv. Rejserne skete $i$ alt slags vejr, om vinteren jævnligt $i$ slæde, og på Bjorholmsminde eksisterer endnu de svære kavajer eller kørekapper, der skærmede mod vind og vejr.

Et forsøg på at bedømme praksis' afkast er vanskeligt og kan kun ske tilnærmelsesvis. Et gennemsnitligt beløb pr. udebesøg over en årrække er cirka 4 mark, altså på 900 besøg cirka 3600 mark. Dertil kommer hjemmekonsultationer, offentlige gebyrer og medicinbesørgelse, der skønnes at have indebåret en fortjeneste. Sammenlagt kunne måske skønnes 6000 mark årligt. Udgifterne har ikke været ringe. 
Fraværet fra hjemmet og kuske- og hjælpetjeneste har nok beslaglagt et par mand løbende. Driften har vel også været forholdsvis dyrere; men slutresultatet har dog stadig været til sognets største indkomst.

En gennemgang af korrespondance og optegnede sygdomstilfælde kunne utvivlsomt bidrage til et nøjere kendskab til driftsformer, dyresygdomme og behandlingsmetoder for nu 100 år siden. Her kan kun uddrages nogle få generelle træk.

Hestene var på Rasmus Bjorholms tid den eneste trækkraft $i$ landbruget, og hestenes sygdomme var hans speciale. Han ses således endog tilkaldt til en amtsforvalter von Manteuffels heste på Brundlund slot i 1880 'erne for at kurere snive. Hestenes fordøjelsessystem er ømfindtligt og $i$ et stort antal tilfælde er anført kolik. Rasmus Bjorholm eksperimenterede med det pulver, der stødtes ned $\mathrm{i}$ halsen på den syge hest, og hans medikamenter var kendt viden om. Ved syge kreaturer er of te angivet betændelser, der dels har varet mælkefeber, dels følger af svære vitamin- og mineralmangler ved forårstide. Fårehold har været meget udbredt på egnens store heder sidst i 1800tallet, og også fårenes sygdomme er meget specielle og yderst vanskelige at kurere. Hvor de har grebet starkt om sig i en fårebesætning, ses en fuldstændig udskiftning ofte tilrådet. Konstant brug af samme areal til fåregræesning er ligeledes frarådet. Endelig har kastrationer været anledning til mange udebesøg, og også på dette felt var dyrlægens ry stort. "Grow renle " giver grunden til, at hans operationer oftest forløb uden alvorlige infektioner. De vanskelige dyrefødsler, der nu er et stort område $i$ en moderne dyrlægepraksis, ses næsten ikke i regnskabsbøgerne. De skulle jo helst overstås inden for nogle timer, og dyrlægen havde ingen mulighed for at komme så hurtigt til stede.

Af mange enkeltheder ses, at Rasmus Bjorholm har holdt sig velorienteret om faglige fremskridt og har trukket både på danske og tyske kilder. Landbohøjskolens dyrlægeuddannelse hørte til Europas bedste $\mathrm{i}$ disse år, og den medicinske industri i Tyskland var samtidig inde $\mathrm{i}$ en stor udvikling. Rasmus Bjorholm tog det bedste, hvor det kunne fås, og administrerede det nøgternt. Hans viden og mange interesser gjorde ham til en velset gast $i$ alle hjem. Der blev set hen til den medfølgende snak, der strejfede alle mulige emner. Han blev jævnligt præsenteret for »kloge folks« råd og meninger. Hørte uden irritation på dem og afgjorde, at det og det var der en fornuft $i$, 
det og det skulle der tros en hel del på. - Studerer man billeder af den unge dyrlæge og senere som ældre, præget af anstrengende arbejde og begyndende sygdom, fortæller hans smukke intelligente ansigt med de store øjne, at her var en personlighed, der gjorde indtryk og vakte sympati og respekt. Med tiden fik han et nxsten legendarisk ry.

Fra det omfattende brevarkiv er hentet et enkelt udpluk:

Bevtoft, bei Ober Jerstal, den 27. Juli 1883.

Geehrter Herr Thierartzt.

Da mein Pferd schon seit 3 Tagen nicht gefressen hat, so wollte ich Sie ersuchen sich mal das Pferd anzusehen, ob es vielleicht an den Zähnen liegt, oder ob ihm sonnst was fehlt.

\section{Bornholtzer}

berittener Gendarm.

Den tyske gendarm i Bevtoft har fremført sit andragende med ulastelig høflighed. Den 31. juli lå hans bolig på dyrlægens vej. I rubrikken sygdom er anført: Kolik fra urent foder. I en tor sommer havde gendarmens ven afbidt gresset for trat og fået jord med.

Hvert år om novembertid lod Rasmus Bjorholm en xldre mand gå rundt og kræve regninger ind. Det lod sig of te praktisk gøre på efterårsmarkederne. $\mathrm{Da}$ blikket faldt på den schneidige gendarms navn, blev der givet besked på: "Hvis staten 5 mark, hvis ham selv ingenting.*

Princippet er jo ikke usædvanligt; men den lune danske gårdmand og dyrlxge har nok ment, at det ingen fejl var, om den gode gendarm kom til at føle sig lidt forpligtet ved lidt venlighed på den ensomme udkommando. Gendarmlønninger var jo ikke store. Den ene hånd, den anden hånd. - Hesten kom sig forøvrigt.

Rasmus Bjorholms død føltes som et stort tab på hans hjemegn. $\mathrm{På} \mathrm{gården} \mathrm{efterfulgtes} \mathrm{han} \mathrm{af} \mathrm{datteren} \mathrm{Bolette} \mathrm{og} \mathrm{svigersønnen} \mathrm{Kre-}$ sten Madsen Petersen fra Hyrup. I praksis overtog dyrlæge Kresten Ries i Toftlund en stor del af kundekredsen, og senere dyrlæge Christian Lund i Agerskov overtog en anden del af den oprindelige store praksis. Begravelsen skete den 19. jan. 1897 på Tislund kirkegård. I 1881 blev H. A. Krüger begravet på Bevtoft kirkegård. Han 
satte en "maksel " eller målestok for begravelsesfølger, som aldrig siden er overtruffet på denne egn. En tysk præst, der så de tusinder af mennesker og hundreder af hestekøretøjer trænge sig i og udenom Bevtoft, har fortalt om den beklemmende følelse denne demonstration af egnens sindelag gjorde på ham: Was haben wir hier zu suchen? Men efter Krügers var Rasmus Bjorholms begravelsesfølge det største på egnen, og heller ikke det er næppe siden overtruffet. 